\title{
Sample size to estimate the mean of morphological traits of rye cultivars in sowing dates and evaluation times
}

\author{
Tamanho de amostra para estimação da média de \\ caracteres morfológicos de cultivares de centeio em épocas de \\ semeadura e de avaliação
}

\author{
Cirineu Tolfo Bandeira ${ }^{1}$; Alberto Cargnelutti Filho ${ }^{2 *}$; Diego Nicolau Follmann²; \\ Cláudia Marques de $\mathrm{Bem}^{3}$; Cleiton Antonio Wartha ${ }^{4}$; Rosana Marzari Thomasi ${ }^{5}$
}

\begin{abstract}
The objectives of this study were to determine the sample size (number of plants) required to estimate the mean of morphological traits of rye (Secale cereale L.) and verify the sample size variability between the traits, cultivars, sowing dates, and evaluation times for distincts mean estimation errors. Ten uniformity trials were performed with two rye cultivars (BRS Progresso and Temprano) in five sowing dates (05/03/2016, 05/25/2016, 06/07/2016, 06/22/2016 and 07/04/2016). Evaluations of traits plant height, number of leaves, and number of stems were performed during the development of the crop. In order to verify the difference of the traits between cultivars and between sowing dates and evaluation times, the F-test was applied to test the hypothesis of homogeneity of variances and the Student's t-test was used to test the hypothesis of equality of means. The sample size of each trait was calculated for distincts mean estimation errors. There is sample size variability between the traits, cultivars, sowing dates, and evaluation times. In order to estimate the mean of plant height with the same precision, smaller sample sizes are required at the intermediate and final evaluation times compared to initial evaluation times. For the traits number of leaves and stems, smaller sample sizes are required in the initial evaluation times than in the final evaluation times. For mean estimation of traits with maximum estimation error of $15 \%$ between sowing dates and evaluation times, 83 and 103 plants are required respectively for cultivars BRS Progresso and Temprano.
\end{abstract}

Key words: Sampling planning. Sampling precision. Secale cereale L.

\section{Resumo}

Os objetivos deste trabalho foram determinar o tamanho de amostra (número de plantas) para a estimação da média de caracteres morfológicos de centeio (Secale cereale L.) e verificar a variabilidade do tamanho de amostra entre caracteres, entre cultivares, entre épocas de semeadura e de avaliação, para distintos erros de estimação da média. Foram conduzidos dez ensaios de uniformidade, com duas cultivares de centeio (BRS Progresso e Temprano) em cinco épocas de semeadura (03/05/2016,

${ }^{1}$ Eng $^{\mathrm{o}}$ Agr ${ }^{\mathrm{o}}$, Discente de Mestrado, Programa de Pós-Graduação em Agronomia, Universidade Federal de Santa Maria, UFSM, Santa Maria, RS, Brasil. E-mail: cirineutolfobandeira@gmail.com

2 Engos Agros, Profs. Drs., Departamento de Fitotecnia, UFSM, Santa Maria, RS, Brasil. E-mail: alberto.cargnelutti.filho@gmail. com; diegonicolaufollmann@gmail.com

3 Zootecnista, Dr ${ }^{\mathrm{a}}$, Programa de Pós-Graduação em Agronomia, UFSM, Santa Maria, RS, Brasil. E-mail: claudia_debem@hotmail. com

${ }^{4}$ Eng $^{\text {o Agr }}{ }^{\text {o }}$, Discente de Mestrado, Programa de Pós-Graduação em Fitotecnia, Universidade Federal de Viçosa, UFV, Viçosa, MG, Brasil. E-mail: cleiton.ufsm@gmail.com

${ }_{5}^{5}$ Discente de Graduação em Agronomia, UFSM, Santa Maria, RS, Brasil. E-mail: rosanamthomasi@hotmail.com

* Author for correspondence 
25/05/2016, 07/06/2016, 22/06/2016 e 04/07/2016). Durante o desenvolvimento da cultura foram realizadas avaliações dos caracteres altura de planta, número de folhas e número de colmos. Para verificar as diferenças dos caracteres, entre cultivares e entre épocas de semeadura e de avaliação, foi aplicado o teste $\mathrm{F}$, para testar a hipótese de homogeneidade de variâncias e o teste $\mathrm{t}$ de Student, para testar a hipótese de igualdade de médias. Foi calculado o tamanho de amostra de cada caractere para distintos erros de estimação da média. Há variabilidade do tamanho de amostra entre os caracteres, cultivares, épocas de semeadura e épocas de avaliação. Para a estimação da média de altura de planta, com mesma precisão, é necessário menor tamanho de amostra nas épocas de avaliação intermediárias e finais comparadas as épocas iniciais de avaliação. Para os caracteres números de folhas e de colmos nas épocas iniciais de avaliação, é necessário tamanho de amostra menor do que em épocas finais de avaliação. São necessárias 83 e 103 plantas, respectivamente, para as cultivares BRS Progresso e Temprano, para a estimação da média dos caracteres, com erro máximo de estimação de $15 \%$, entre épocas de semeadura e entre épocas de avaliação.

Palavras-chave: Planejamento amostral. Precisão amostral. Secale cereale L.

\section{Introduction}

Rye (Secale cereale L.) belongs to the Poaceae family and is planted annually during winter and matures earlier than many other cereals, but has a long reproductive cycle (BAIER, 1994). In Brazil, the primary states that grow rye are Rio Grande do Sul and Paraná; the cultivation area of rye is approximately 2,500 ha and average yield of rye is $2,600 \mathrm{~kg} \mathrm{ha}^{-1}$ (CONAB, 2017). Rye has vigorous initial growth and has high productivity as measured in dry matter weight. In the agricultural sector, rye is important as a forage crop, cover crop, and is an important production grain. Its straw has a high carbon: nitrogen ratio and rye is suitable as a soil cover crop, as well as in the management of soil erosion and reduction of $\mathrm{NO}_{3}$ losses (PANTOJA et al., 2016). The use of grasses in monoculture or in consortium has a greater potential for soil protection because of the prolonged presence of their remnants on the soil surface (ZIECH et al., 2015).

The high demands of time, labor, and financial resources hamper the evaluation and measurement of a large number of traits of plants in agricultural experiments. Thus, efficient sampling for the desired measurements is needed. Further, sample size is important in obtaining accurate estimates of the parameters in question. The sample size needed depends on the variability in the data and the desired degree of confidence, which are determined by the researcher (BUSSAB; MORETTIN, 2013). Sample size interferes with the interpretation of significance of statistical tests, as small samples can generate inaccurate estimates, which are less likely to occur with large sample sizes. However, larger samples can generate deflated $P$-values (i.e., indicating statistical significance in the absence of practical significance (LIN et al., 2013).

Scenarios formed by cultivars, sowing dates, and evaluation times during the crop cycle are important for the determination of sample size. Data that cover the range of variation in traits of interest better represent the crop, and these data help generate the capacity to estimate needed sample sizes that can be used as a reference for planning of future experiments. The need for variability in sample sizes to estimate means and associated errors for plant traits, cultivars, sowing dates, and evaluation times have been reported for crops such as maize (STORCK et al., 2007), castor bean (CARGNELUTTI FILHO et al., 2010), black oat (CARGNELUTTI FILHO et al., 2015), pigeon pea (FACCO et al., 2015, 2016), Crotalaria juncea, and Crotalaria spectabilis Roth (TEODORO et al., 2015).

Studies regarding sample sizes needed to estimate the mean of morphological traits in rye for BRS Progresso and Temprano cultivars were not found in the literature and we assumed that 
there is variability in sample size needed to assess traits, cultivars, sowing dates, and evaluation times. The objectives of this study were to determine the sample size (number of plants) required to estimate the means of morphological traits of rye (Secale cereale L.) and verify that for a given level of statistical confidence, sample sizes varies for traits, cultivars, sowing dates, and evaluation times.

\section{Material and Methods}

Ten uniformity trials (blank experiments) were performed with rye (Secale cereale L.), in the experimental area of the Department of Plant Science at the Federal University of Santa Maria, Rio Grande do Sul in Southern Brazil $\left(29^{\circ} 42^{\prime} \mathrm{S}\right.$, $53^{\circ} 49^{\prime} \mathrm{W}$; elevation $=95 \mathrm{~m}$ ) during the 2016 growing season. According to the Köppen Climate Classification, the climate of the region is $\mathrm{Cfa}$ subtropical humid, with hot summers and no defined dry season (HELDWEIN et al., 2009). The soil is classified as sandy loam typic Paleudalf (SANTOS et al., 2013).

Conventional soil tillage was carried out with light harrowing and basic fertilization was performed with $500 \mathrm{~kg} \mathrm{ha}^{-1}$ of NPK fertilizer (520-20) being applied. In these uniformity trials, procedures of sowing, fertilization, cultural practices, and evaluations were performed homogeneously throughout the experimental area. Two cultivars (BRS Progresso and Temprano) were sown at five dates: 05/03/2016 (Sowing date 1), 05/25/2016 (Sowing date 2), 06/07/2016 (Sowing date 3), 06/22/2016 (Sowing date 4), and 04/07/2016 (Sowing date 5). Seeds from the BRS Progresso and Temprano cultivars were sown by broadcasting at a seed density of 455 seeds $\mathrm{m}^{-2}$. The choice of cultivars was based on their suitability for use in this region. The BRS Progresso cultivar is destined for grain production and Temprano is recommended as a forage and cover crop. Each cultivar was sown in an area of $320 \mathrm{~m}^{2}(20 \mathrm{~m} \times 16 \mathrm{~m})$ at the first sowing date, whereas each cultivar occupied $375 \mathrm{~m}^{2}(25 \mathrm{~m}$ $\times 15 \mathrm{~m})$ at the other sowing dates.

In the central area of $100 \mathrm{~m}^{2}(10 \mathrm{~m} \times 10 \mathrm{~m})$ in each uniformity trial, a grid with 100 sample points was marked with stakes spaced at $1 \mathrm{~m} \times 1 \mathrm{~m}$, forming a matrix of ten rows and ten columns. The closest plant to the sampling stake was measured at each sampling point. In these sampled plants, plant height $(\mathrm{PH}$, in $\mathrm{cm}$; measured as the distance from the soil surface to the insertion of the last leaf on the stem), number of leaves per plant (NL; leaves of the main stem + leaves of the tillers), and the number of stems per plant (NS; main stem + stems of the tillers) were recorded.

Evaluations were carried out from the beginning of crop development until flowering (Table 1). Measurements were collected using the same methodology for all sowing dates, respecting the dates of planting and plant development for each sowing date.

The mean $(\mathrm{m})$ and variance $\left(\mathrm{s}^{2}\right)$ were calculated at each sowing date for each trait, cultivar, and evaluation time. The $F$-test (unilateral), at $5 \%$ of error probability was used to test homogeneity of variance and the $t$-test (bilateral) at $5 \%$ of error probability for independent samples was performed to test the hypothesis of equality of means. Initially, the tests were applied to the data from the last evaluation (i.e., the evaluation performed at the flowering stage of the crop). The cultivars were compared for each sowing date with these data. Afterwards, the sowing dates were compared in each cultivar. Then, with data from all evaluations, evaluation times were compared within each combination of cultivar and sowing date. Nonnormally distributed data were assessed using the Kolmogorov-Smirnov test and data randomness was checked by the run test (CAMPOS, 1983). The sample size $(n)$ was calculated for the confidence interval half-lengths (estimation errors) of 5, $10,15,20$, and $25 \%$ of the estimate of the mean with confidence level (1- $\alpha)$ of $95 \%$, following 
the formula: $n=\frac{t_{\alpha / 2}^{2} s^{2}}{{\text { estimation error })^{2}}^{2} \quad(B U S S A B ;} \quad$ is equal to $\alpha / 2$ (i.e., the value of $\mathrm{t}$ such that: $\mathrm{P}\left(\mathrm{t}>\mathrm{t}_{\alpha / 2}\right)$ MORETTIN, 2013), where: $t_{\alpha / 2}$ is the critical value $=\alpha / 2$, with $(n-1)$ degrees of freedom, with $\alpha=5 \%$ of of the Student's $t$ distribution, whose area on the right probability of error) and, $\mathrm{s}^{2}$ is the estimate of variance.

Table 1. Evaluation times in days after sowing of the traits plant height, number of leaves, and number of stems in two rye cultivars in five sowing dates.

\begin{tabular}{|c|c|c|c|c|c|}
\hline \multirow[b]{2}{*}{ Evaluation } & \multicolumn{5}{|c|}{ Sowing date } \\
\hline & $\begin{array}{c}1 \\
(05 / 03 / 2016)\end{array}$ & $\begin{array}{c}2 \\
(05 / 25 / 2016)\end{array}$ & $\begin{array}{c}3 \\
(06 / 07 / 2016)\end{array}$ & $\begin{array}{c}4 \\
(06 / 22 / 2016)\end{array}$ & $\begin{array}{c}5 \\
(07 / 04 / 2016)\end{array}$ \\
\hline & \multicolumn{5}{|c|}{ - } \\
\hline 1 & 22 & 20 & 22 & 16 & 24 \\
\hline 2 & 29 & 28 & 28 & 20 & 29 \\
\hline 3 & 36 & 34 & 35 & 27 & 36 \\
\hline 4 & 42 & 41 & 42 & 36 & 43 \\
\hline 5 & 50 & 49 & 51 & 41 & 50 \\
\hline 6 & 56 & 55 & 56 & 50 & 58 \\
\hline 7 & 66 & 65 & 63 & 55 & 66 \\
\hline 8 & 71 & 69 & 73 & 64 & 72 \\
\hline \multirow[t]{2}{*}{9} & 97 & 99 & 100 & 92 & 87 \\
\hline & \multicolumn{5}{|c|}{ 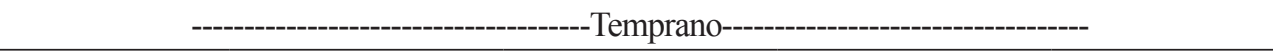 } \\
\hline 1 & 22 & 20 & 22 & 16 & 24 \\
\hline 2 & 29 & 28 & 28 & 20 & 29 \\
\hline 3 & 36 & 34 & 35 & 27 & 36 \\
\hline 4 & 42 & 41 & 42 & 36 & 43 \\
\hline 5 & 50 & 49 & 51 & 41 & 50 \\
\hline 6 & 56 & 55 & 56 & 50 & 58 \\
\hline 7 & 66 & 65 & 63 & 55 & 66 \\
\hline 8 & 71 & 69 & 72 & 63 & 72 \\
\hline 9 & 92 & 92 & 93 & 85 & 95 \\
\hline 10 & 113 & 131 & 125 & 121 & 120 \\
\hline 11 & 142 & - & - & - & - \\
\hline
\end{tabular}

Based on the formula used to calculate the sample size, $n$ was set at 100 plants and the estimation error was calculated as a percentage of the estimate of the mean $(\mathrm{m})$ for each trait, using the formula: estimation error $=100 \frac{t_{\alpha / 2} s}{\sqrt{n} m}$, where $\mathrm{s}$ is the estimate of standard deviation. Statistical analyses were performed using GENES software (CRUZ, 2013) and Microsoft Excel ${ }^{\circledR}$.

\section{Results and Discussion}

There were differences between the means of plant height for the cultivars at the flowering stage shown by the Student's $t$-test only for the first sowing date. The number of leaves per plant was greater in the BRS Progresso cultivar for sowing dates 1 and 4. However, there was superiority of the Temprano cultivar over BRS Progresso for the number of stems 
per plant at sowing dates 2,4 , and 5 . The variances were heterogeneous for $80 \%$ of the cases, indicating that the sample size should be different between the cultivars (Table 2). Differences in sample size were observed between maize (STORCK et al.,
2007) and soybean genotypes (CARGNELUTTI FILHO et al., 2009), between castor bean hybrids (CARGNELUTTI FILHO et al., 2010), and between species of crotalaria (TEODORO et al., 2015).

Table 2. Mean and variance of traits plant height (PH, in $\mathrm{cm}$ ), number of leaves per plant (NL), and number of stems per plant (NS) at the flowering stage of two rye cultivars (BRS Progresso and Temprano), Student's t-test results for comparison of means, and F-test for comparison of variances of rye cultivars in five sowing dates.

\begin{tabular}{|c|c|c|c|c|c|c|}
\hline \multirow{2}{*}{ Trait } & \multicolumn{3}{|c|}{---------------Mean--------------- } & \multicolumn{3}{|c|}{------------------Variance------------------- } \\
\hline & BRS Progresso & Temprano & t-test & BRS Progresso & Temprano & F-test \\
\hline & \multicolumn{6}{|c|}{ Sowing date $1(05 / 03 / 2016)$} \\
\hline $\mathrm{PH}$ & 101.83 & 114.32 & $*$ & 158.15 & 294.01 & Heterogeneous \\
\hline NL & 10.98 & 7.74 & $*$ & 41.43 & 20.76 & Heterogeneous \\
\hline \multirow[t]{2}{*}{ NS } & 2.81 & 2.72 & ns & 2.58 & 2.51 & Homogeneous \\
\hline & \multicolumn{6}{|c|}{ Sowing date $2(05 / 25 / 2016)$} \\
\hline $\mathrm{PH}$ & 118.60 & 120.97 & ns & 299.70 & 480.88 & Heterogeneous \\
\hline NL & 20.30 & 20.97 & ns & 110.01 & 189.77 & Heterogeneous \\
\hline \multirow[t]{2}{*}{ NS } & 5.08 & 6.33 & $*$ & 5.31 & 23.40 & Heterogeneous \\
\hline & \multicolumn{6}{|c|}{ Sowing date $3(06 / 07 / 2016)$} \\
\hline $\mathrm{PH}$ & 126.44 & 126.91 & ns & 183.99 & 434.83 & Heterogeneous \\
\hline NL & 11.62 & 12.64 & ns & 25.73 & 49.30 & Heterogeneous \\
\hline \multirow[t]{2}{*}{ NS } & 3.28 & 3.67 & ns & 2.37 & 3.64 & Heterogeneous \\
\hline & \multicolumn{6}{|c|}{ Sowing date $4(06 / 22 / 2016)$} \\
\hline $\mathrm{PH}$ & 118.34 & 122.56 & ns & 158.09 & 469.35 & Heterogeneous \\
\hline NL & 10.73 & 7.65 & $*$ & 23.69 & 18.80 & Homogeneous \\
\hline \multirow[t]{2}{*}{ NS } & 2.83 & 3.71 & $*$ & 1.27 & 5.22 & Heterogeneous \\
\hline & \multicolumn{6}{|c|}{ Sowing date $5(07 / 04 / 2016)$} \\
\hline $\mathrm{PH}$ & 107.92 & 110.52 & ns & 340.21 & 356.70 & Homogeneous \\
\hline NL & 6.68 & 7.49 & ns & 11.49 & 31.55 & Heterogeneous \\
\hline NS & 2.08 & 3.32 & * & 1.35 & 4.06 & Heterogeneous \\
\hline
\end{tabular}

*Means differ by bilateral t-test at 5\% of error probability. ns: not significant. Heterogeneous: heterogeneous variances by bilateral F-test at $5 \%$ probability of error. Homogeneous: homogeneous variances.

There was a distinct behavior of cultivars between sowing dates. The difference between mean $\mathrm{PH}$ values was not significant in one case (sowing dates 2 and 4 ) and in three cases (sowing dates 1 and 5, 2 and 4, and 3 and 4) respectively for BRS Progresso and Temprano (Table3). Therefore, the BRS Progresso cultivar was more influenced by the environment than Temprano for the $\mathrm{PH}$ trait. The NL mean in the BRS Progresso cultivar was different for many sowing dates, except in the comparison of sowing date 1 with sowing dates 3 and 4, and sowing date 3 with sowing date 4 . Meanwhile, Temprano means were not different between sowing dates 1 and 4 , or 1 and 5 , and sowing dates 4 and 5. For the NS trait, the mean was not different between sowing dates 1 and 4 for 
BRS Progresso. The same trait was not different for Temprano between sowing dates 3 and 4, 3 and 5, and 4 and 5. This demonstrated that sowing date affected the traits in question, as the lowest values were found consistently for the first and last sowing dates. When comparing variances, at least in $60 \%$ and $30 \%$ of the comparisons respectively for BRS Progresso and Temprano, variances were heterogeneous, which suggests different sample sizes are needed for different sowing dates.

Table 3. Results of Student's t test (above diagonal) for comparison of means (diagonal) and F-test (below diagonal) for comparison of variances between sowing dates in rye cultivars BRS Progresso and Temprano at flowering stage.

\begin{tabular}{|c|c|c|c|c|c|c|c|c|c|c|}
\hline & \multicolumn{5}{|c|}{ - } & \multicolumn{5}{|c|}{ 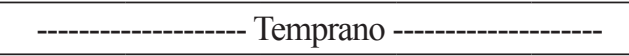 } \\
\hline & 1 & 2 & 3 & 4 & 5 & 1 & 2 & 3 & 4 & 5 \\
\hline & \multicolumn{10}{|c|}{ Plant height } \\
\hline 1 & $101.83^{(1)}$ & $*$ & $*$ & $*$ & $*$ & 114.32 & $*$ & $*$ & $*$ & ns \\
\hline 2 & Het & 118.60 & $*$ & ns & * & Het & 120.97 & * & ns & $*$ \\
\hline 3 & Hom & Het & 126.44 & $*$ & $*$ & Het & Hom & 126.91 & ns & $*$ \\
\hline 4 & Hom & Het & Hom & 118.34 & $*$ & Het & Hom & Hom & 122.56 & $*$ \\
\hline \multirow[t]{2}{*}{5} & Het & Hom & Het & Het & 107.92 & Hom & Hom & Hom & Hom & 110.52 \\
\hline & \multicolumn{10}{|c|}{ Number of leaves per plant } \\
\hline 1 & 10.98 & $*$ & ns & ns & $*$ & 7.74 & $*$ & $*$ & ns & ns \\
\hline 2 & Het & 20.30 & $*$ & $*$ & $*$ & Het & 20.97 & $*$ & $*$ & $*$ \\
\hline 3 & Het & Het & 11.62 & ns & $*$ & Het & Het & 12.64 & $*$ & $*$ \\
\hline 4 & Het & Het & Hom & 10.73 & $*$ & Hom & Het & Het & 7.65 & ns \\
\hline \multirow[t]{2}{*}{5} & Het & Het & Het & Het & 6.68 & Het & Het & Het & Het & 7.49 \\
\hline & \multicolumn{10}{|c|}{ Number of stems per plant } \\
\hline 1 & 2.81 & $*$ & $*$ & ns & $*$ & 2.72 & $*$ & $*$ & $*$ & $*$ \\
\hline 2 & Het & 5.08 & $*$ & $*$ & $*$ & Het & 6.33 & $*$ & $*$ & $*$ \\
\hline 3 & Hom & Het & 3.28 & $*$ & $*$ & Het & Het & 3.67 & $\mathrm{~ns}$ & ns \\
\hline 4 & Het & Het & Het & 2.83 & $*$ & Het & Het & Het & 3.71 & $\mathrm{~ns}$ \\
\hline 5 & Het & Het & Het & Hom & 2.08 & Het & Het & Hom & Hom & 3.32 \\
\hline
\end{tabular}

*Means differ by bilateral t-test at $5 \%$ of error probability. ns: not significant. Heterogeneous: heterogeneous variances by bilateral F-test at 5\% probability of error. Homogeneous: homogeneous variances. ${ }^{(1)}$ Mean of traits of the rye cultivars in sowing dates at flowering stage.

There were differences for $\mathrm{PH}$ in both cultivars and for all sowing dates, showing that there was a difference between evaluation times for each cultivar. There were differences between NL and NS traits in BRS Progresso and Temprano cultivars for most evaluation times. When comparing the variances at evaluation times for BRS Progresso, the variances were heterogeneous at least in 88.89 , 80.56 , and $63.89 \%$ of the comparisons respectively for PH, NL, and NS traits. For the Temprano cultivar, the variances were heterogeneous at least in 89.09 , 88.89 , and $68.89 \%$ of the comparisons respectively for PH, NL, and NS traits (Table 4). Therefore, the sample size to estimate the mean should be different between the evaluation times.

These results corroborate those reported by Facco et al. (2015), who verified that the optimal sample size in pigeon pea depends on the morphological trait being investigated and evaluation time. Also, 
the needed sample size varied with the productive trait and harvest for this same crop (FACCO et al., 2016).

The data adjusted to the normal distribution by the Kolmogorov-Smirnov test and were randomized according to the run test (CAMPOS,
1983) respectively in $53.13 \%$ and $76.39 \%$ of the 288 cases $(3$ traits $\times 2$ cultivars $\times 5$ sowing dates $\times$ 9,10 , or 11 evaluation times). The sample size was calculated based on the Student's $t$ distribution as the majority of cases had normally distributed data and randomness associated with the great number of plants sampled in each case $(n=100$ plants).

Table 4. Number of significant $\left({ }^{*}\right)$ and non-significant (ns) results by the Student's t-test and number of results of comparison of variances (heterogeneous and homogeneous) by the F-test during the evaluation times of plant height $(\mathrm{PH})$, number of leaves per plant (NL), and number of stems per plant (NS) of rye cultivars BRS Progresso and Temprano.

\begin{tabular}{|c|c|c|c|c|c|c|c|c|}
\hline \multirow{3}{*}{ Trait } & \multicolumn{4}{|c|}{ - BRS Progresso(1) } & \multicolumn{4}{|c|}{ 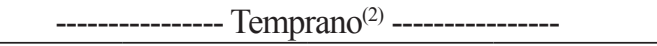 } \\
\hline & \multicolumn{2}{|c|}{-- t-test -- } & \multicolumn{2}{|c|}{ - } & \multicolumn{2}{|c|}{-- t-test -- } & \multicolumn{2}{|c|}{ 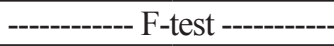 } \\
\hline & $*$ & $\mathrm{~ns}$ & Het & Hom & * & ns & Het & Hom \\
\hline & \multicolumn{8}{|c|}{ Sowing date $1(05 / 03 / 2016)$} \\
\hline $\mathrm{PH}$ & 36 & 0 & 34 & 2 & 55 & 0 & 49 & 6 \\
\hline NL & 34 & 2 & 33 & 3 & 53 & 2 & 51 & 4 \\
\hline \multirow[t]{2}{*}{ NS } & 28 & 8 & 31 & 5 & 52 & 3 & 51 & 4 \\
\hline & \multicolumn{8}{|c|}{ Sowing date $2(05 / 25 / 2016)$} \\
\hline $\mathrm{PH}$ & 36 & 0 & 36 & 0 & 45 & 0 & 43 & 2 \\
\hline NL & 32 & 4 & 31 & 5 & 41 & 4 & 45 & 0 \\
\hline \multirow[t]{2}{*}{ NS } & 31 & 5 & 24 & 12 & 42 & 3 & 31 & 14 \\
\hline & \multicolumn{8}{|c|}{ Sowing date $3(06 / 07 / 2016)$} \\
\hline $\mathrm{PH}$ & 36 & 0 & 35 & 1 & 45 & 0 & 43 & 2 \\
\hline NL & 31 & 5 & 29 & 7 & 39 & 6 & 40 & 5 \\
\hline \multirow[t]{2}{*}{ NS } & 33 & 3 & 23 & 13 & 41 & 4 & 32 & 13 \\
\hline & \multicolumn{8}{|c|}{ Sowing date $4(06 / 22 / 2016)$} \\
\hline PH & 36 & 0 & 32 & 4 & 45 & 0 & 41 & 4 \\
\hline NL & 32 & 4 & 34 & 2 & 43 & 2 & 40 & 5 \\
\hline \multirow[t]{2}{*}{ NS } & 29 & 7 & 25 & 11 & 43 & 2 & 33 & 12 \\
\hline & \multicolumn{8}{|c|}{ Sowing date $5(07 / 04 / 2016)$} \\
\hline $\mathrm{PH}$ & 36 & 0 & 33 & 3 & 45 & 0 & 45 & 0 \\
\hline NL & 29 & 7 & 30 & 6 & 42 & 3 & 43 & 2 \\
\hline NS & 31 & 5 & 26 & 10 & 38 & 7 & 37 & 8 \\
\hline
\end{tabular}

*Means differ by bilateral t-test at $5 \%$ of error probability. ns: not significant. Heterogeneous: heterogeneous variances by bilateral F-test at 5\% probability of error. Homogeneous: homogeneous variances. (1) In this cultivar, 36 combinations of evaluation times are possible in each sowing date for comparison of means. (2) In this cultivar, 55 and 45 combinations of evaluation times are possible respectively for sowing date 1 and other sowing dates for comparison of means. 
The sample size for the estimation of the mean of each trait in evaluation times, based on a $95 \%$ confidence interval, ranged from 18 plants for $\mathrm{PH}$ traits in the ninth evaluation (flowering) of sowing date 4 in the BRS Progresso cultivar to 920 plants for NS trait in the tenth evaluation of sowing date 2 in the Temprano cultivar (Tables 5, 6). Therefore, there was great variability in sample size between traits, cultivars, sowing dates, and evaluation times. Thus, 920 rye plants are required to assess differences in means of the traits, cultivars, sowing dates, or evaluation times, at a confidence level of $95 \%$ and an error of $5 \%$ of the estimate of the mean.
From a practical point of view, there are difficulties in evaluating 920 rye plants. Thus, sample sizes with $10,15,20$, and $25 \%$ estimation errors were determined (Tables 5, 6). Accepting larger estimation errors provides researchers the flexibility to use sample sizes according to the desired accuracy to meet research needs. Based on the largest sample size between the traits $\mathrm{PH}, \mathrm{NL}$, and NS, cultivars, sowing dates, and evaluation times with an estimation error of $15 \%$ and $95 \%$ level of confidence, 103 plants are required to evaluate the mean of these traits. Thus, in an experimental design with four replications, 26 plants per replication of each treatment should be evaluated.

Table 5. Sample size (number of plants) to estimate the mean of the traits plant height, number of leaves per plant, and number of stems per plant in the rye cultivar BRS Progresso for the estimation errors equal to $5 \%, 10 \%, 15 \%, 20 \%$, and $25 \%$ of the mean $(\mathrm{m})$ in sowing dates and evaluation times $(\mathrm{E})$.

\begin{tabular}{|c|c|c|c|c|c|c|c|c|c|c|c|c|c|c|c|c|c|c|}
\hline $\mathrm{E}$ & 5 & 10 & 15 & 20 & 25 & $\begin{array}{c}\text { Error } \\
(\%)\end{array}$ & 5 & 10 & 15 & 20 & 25 & $\begin{array}{c}\text { Error } \\
(\%)\end{array}$ & 5 & 10 & 15 & 20 & 25 & $\begin{array}{c}\text { Error } \\
(\%)\end{array}$ \\
\hline & \multicolumn{6}{|c|}{ Plant height } & \multicolumn{6}{|c|}{ Number of leaves per plant } & \multicolumn{6}{|c|}{ Number of stems per plant } \\
\hline \multicolumn{19}{|c|}{ Sowing date $1(05 / 03 / 2016)$} \\
\hline 1 & 220 & 55 & 25 & 14 & 9 & 7.41 & 92 & 23 & 11 & 6 & 4 & 4.77 & 196 & 49 & 22 & 13 & 8 & 6.99 \\
\hline 2 & 123 & 31 & 14 & 8 & 5 & 5.52 & 94 & 24 & 11 & 6 & 4 & 4.84 & 185 & 47 & 21 & 12 & 8 & 6.79 \\
\hline 3 & 109 & 28 & 13 & 7 & 5 & 5.22 & 105 & 27 & 12 & 7 & 5 & 5.12 & 203 & 51 & 23 & 13 & 9 & 7.12 \\
\hline 4 & 136 & 34 & 16 & 9 & 6 & 5.82 & 175 & 44 & 20 & 11 & 7 & 6.61 & 194 & 49 & 22 & 13 & 8 & 6.96 \\
\hline 5 & 165 & 42 & 19 & 11 & t & 6.41 & 226 & 57 & 26 & 15 & 10 & 7.50 & 253 & 64 & 29 & 16 & 11 & 7.94 \\
\hline 6 & 180 & 45 & 20 & 12 & 8 & 6.70 & & 50 & 23 & 13 & 8 & & 448 & 112 & 50 & 28 & 18 & 10.58 \\
\hline 7 & 189 & 48 & 21 & 12 & 8 & 6.86 & & 107 & 48 & 27 & 18 & 10.34 & 440 & 110 & 49 & 28 & 18 & 10.48 \\
\hline 8 & 149 & 38 & 17 & 10 & 6 & 6.09 & 290 & 73 & 33 & 19 & 12 & 8.51 & 427 & 107 & 48 & 27 & 18 & 10.33 \\
\hline 9 & 25 & 7 & 3 & 2 & 1 & 2.45 & 542 & 136 & 61 & 34 & 22 & 11.63 & 515 & 129 & 58 & 33 & 21 & 11.34 \\
\hline \multicolumn{19}{|c|}{ Sowing date $2(05 / 25 / 2016)$} \\
\hline 1 & 159 & 40 & 18 & 10 & 1 & 6.29 & 44 & 11 & 5 & 3 & 2 & 3.30 & -(1) & - & - & - & - & - \\
\hline 2 & 116 & 29 & 13 & 8 & 5 & 5.37 & 84 & 21 & 10 & 6 & 4 & 4.57 & 49 & 13 & 6 & 4 & 2 & 3.47 \\
\hline 3 & 117 & 30 & 13 & 8 & 5 & 5.39 & 96 & 24 & 11 & 6 & 4 & 4.90 & 124 & 31 & 14 & 8 & 5 & 5.57 \\
\hline 4 & 96 & 24 & 11 & 6 & 4 & 4.88 & 143 & 36 & 16 & 9 & 6 & 5.98 & 175 & 44 & 20 & 11 & 7 & 6.60 \\
\hline 5 & 111 & 28 & 13 & 7 & 5 & 5.27 & 161 & 41 & 18 & 11 & 7 & 6.33 & 323 & 81 & 36 & 21 & 13 & 8.97 \\
\hline 6 & 120 & 30 & 14 & 8 & 5 & 5.48 & 216 & 54 & 24 & 14 & 9 & 7.34 & 357 & 90 & 40 & 23 & 15 & 9.44 \\
\hline 7 & 131 & 33 & 15 & 9 & 6 & 5.70 & 320 & 80 & 36 & 20 & 13 & 8.94 & 742 & 186 & 83 & 47 & 30 & 13.61 \\
\hline 8 & 120 & 30 & 14 & 8 & 5 & 5.48 & 297 & 75 & 33 & 19 & 12 & 8.61 & 420 & 105 & 47 & 27 & 17 & 10.24 \\
\hline 9 & 34 & 9 & 4 & 3 & 2 & 2.90 & 421 & 106 & 47 & 27 & 17 & 10.25 & 324 & 81 & 36 & 21 & 13 & 9.00 \\
\hline
\end{tabular}


continuation

\begin{tabular}{|c|c|c|c|c|c|c|c|c|c|c|c|c|c|c|c|c|c|c|}
\hline \multicolumn{19}{|c|}{ Sowing date $3(06 / 07 / 2016)$} \\
\hline 1 & 131 & 33 & 15 & 9 & 6 & 5.72 & 188 & 47 & 21 & 12 & 8 & 6.84 & - & - & - & - & - & - \\
\hline 2 & 82 & 21 & 10 & 6 & 4 & 4.51 & 48 & 12 & 6 & 3 & 2 & 3.45 & 76 & 19 & 9 & 5 & 4 & 4.34 \\
\hline 3 & 75 & 19 & 9 & 5 & 3 & 4.32 & 71 & 18 & 8 & 5 & 3 & 4.20 & 60 & 15 & 7 & 4 & 3 & 3.86 \\
\hline 4 & 92 & 23 & 11 & 6 & 4 & 4.78 & 74 & 19 & 9 & 5 & 3 & 4.30 & 102 & 26 & 12 & 7 & 5 & 5.03 \\
\hline 5 & 68 & 17 & 8 & 5 & 3 & 4.10 & 142 & 36 & 16 & 9 & 6 & 5.96 & 237 & 60 & 27 & 15 & 10 & 7.69 \\
\hline 6 & 66 & 17 & 8 & 5 & 3 & 4.05 & 215 & 54 & 24 & 14 & 9 & 7.31 & 182 & 46 & 21 & 12 & 8 & 6.74 \\
\hline 7 & 88 & 22 & 10 & 6 & 4 & 4.68 & 204 & 51 & 23 & 13 & 9 & 7.14 & 196 & 49 & 22 & 13 & 8 & 7.00 \\
\hline 8 & 43 & 11 & 5 & 3 & 2 & 3.27 & 196 & 49 & 22 & 13 & 8 & 7.00 & 203 & 51 & 23 & 13 & 9 & 7.12 \\
\hline 9 & 19 & 5 & 3 & 2 & 1 & 2.13 & 301 & 76 & 34 & 19 & 13 & 8.66 & 347 & 87 & 39 & 22 & 14 & 9.30 \\
\hline \multicolumn{19}{|c|}{ Sowing date $4(06 / 22 / 2016)$} \\
\hline 1 & 149 & 38 & 17 & 10 & 6 & 6.08 & 127 & 32 & 15 & 8 & 6 & 5.61 & - & - & - & - & - & - \\
\hline 2 & 70 & 18 & 8 & 5 & 3 & 4.17 & 50 & 13 & 6 & 4 & 2 & 3.51 & 107 & 27 & 12 & 7 & 5 & 5.15 \\
\hline 3 & 48 & 12 & 6 & 3 & 2 & 3.44 & 89 & 23 & 10 & 6 & 4 & 4.71 & 121 & 31 & 14 & 8 & 5 & 5.48 \\
\hline 4 & 89 & 23 & 10 & 6 & 4 & 4.71 & 90 & 23 & 10 & 6 & 4 & 4.72 & 123 & 31 & 14 & 8 & 5 & 5.53 \\
\hline 5 & 83 & 21 & 10 & 6 & 4 & 4.54 & 106 & 27 & 12 & 7 & 5 & 5.13 & 139 & 35 & 16 & 9 & 6 & 5.88 \\
\hline 6 & 87 & 22 & 10 & 6 & 4 & 4.64 & 105 & 27 & 12 & 7 & 5 & 5.10 & 166 & 42 & 19 & 11 & 7 & 6.44 \\
\hline 7 & 118 & 30 & 14 & 8 & 5 & 5.41 & 159 & 40 & 18 & 10 & 7 & 6.30 & 168 & 42 & 19 & 11 & 7 & 6.47 \\
\hline 8 & 69 & 18 & 8 & 5 & 3 & 4.14 & 221 & 56 & 25 & 14 & 9 & 7.43 & 289 & 73 & 33 & 19 & 12 & 8.49 \\
\hline 9 & 18 & 5 & 2 & 2 & 1 & 2.11 & 325 & 82 & 37 & 21 & 13 & 9.00 & 251 & 63 & 28 & 16 & 11 & 7.91 \\
\hline \multicolumn{19}{|c|}{ Sowing date $5(07 / 04 / 2016)$} \\
\hline 1 & 92 & 23 & 11 & 6 & 4 & 4.79 & 58 & 15 & 7 & 4 & 3 & 3.78 & 172 & 43 & 20 & 11 & 7 & 6.55 \\
\hline 2 & 108 & 27 & 12 & 7 & 5 & 5.19 & 46 & 12 & 6 & 3 & 2 & 3.37 & 65 & 17 & 8 & 5 & 3 & 4.00 \\
\hline 3 & 83 & 21 & 10 & 6 & 4 & 4.55 & 112 & 28 & 13 & 7 & 5 & 5.27 & 89 & 23 & 10 & 6 & 4 & 4.71 \\
\hline 4 & 107 & 27 & 12 & 7 & 5 & 5.17 & 173 & 44 & 20 & 11 & 7 & 6.57 & 203 & 51 & 23 & 13 & 9 & 7.12 \\
\hline 5 & 140 & 35 & 16 & 9 & 6 & 5.92 & 235 & 59 & 27 & 15 & 10 & 7.66 & 203 & 51 & 23 & 13 & 9 & 7.12 \\
\hline 6 & 114 & 29 & 13 & 8 & 5 & 5.32 & 249 & 63 & 28 & 16 & 10 & 7.88 & 291 & 73 & 33 & 19 & 12 & 8.53 \\
\hline 7 & 81 & 21 & 9 & 6 & 4 & 4.49 & 280 & 70 & 32 & 18 & 12 & 8.35 & 381 & 96 & 43 & 24 & 16 & 9.75 \\
\hline 8 & 65 & 17 & 8 & 5 & 3 & 4.02 & 416 & 104 & 47 & 26 & 17 & 10.19 & 415 & 104 & 47 & 26 & 17 & 10.18 \\
\hline 9 & 47 & 12 & 6 & 3 & 2 & 3.39 & 406 & 102 & 46 & 26 & 17 & 10.07 & 491 & 123 & 55 & 31 & 20 & 11.07 \\
\hline
\end{tabular}

(1)It was not possible to calculate the sample size because there was no variance in the data (plants presented only one stem). 
Table 6. Sample size (number of plants) to estimate the mean of the traits plant height, number of leaves per plant, and number of stems per plant in the rye cultivar Temprano for the estimation errors equal to $5 \%, 10 \%, 15 \%, 20 \%$, and $25 \%$ of the mean $(\mathrm{m})$ in sowing dates and evaluation times (E).

\begin{tabular}{|c|c|c|c|c|c|c|c|c|c|c|c|c|c|c|c|c|c|c|}
\hline $\mathrm{E}$ & 5 & 10 & 15 & 20 & 25 & $\begin{array}{l}\text { Error } \\
(\%)\end{array}$ & 5 & 10 & 15 & 20 & 25 & $\begin{array}{c}\text { Error } \\
(\%)\end{array}$ & 5 & 10 & 15 & 20 & 25 & $\begin{array}{l}\text { Error } \\
(\%)\end{array}$ \\
\hline & \multicolumn{6}{|c|}{ Plant height } & \multicolumn{6}{|c|}{ Number of leaves per plant } & \multicolumn{6}{|c|}{ Number of stems per plant } \\
\hline \multicolumn{19}{|c|}{ Sowing date $1(05 / 03 / 2016)$} \\
\hline 1 & 111 & 28 & 13 & 7 & 5 & 5.26 & 102 & 26 & 12 & 7 & 5 & 5.03 & 160 & 40 & 18 & 10 & 7 & 6.31 \\
\hline 2 & 78 & 20 & 9 & 5 & 4 & 4.39 & 87 & 22 & 10 & 6 & 4 & 4.66 & 135 & 34 & 15 & 9 & 6 & 5.80 \\
\hline 3 & 70 & 18 & 8 & 5 & 3 & 4.17 & 80 & 20 & 9 & 5 & 4 & 4.46 & 81 & 21 & 9 & 6 & 4 & 4.50 \\
\hline 4 & 61 & 16 & 7 & 4 & 3 & 3.90 & 116 & 29 & 13 & 8 & 5 & 5.37 & 134 & 34 & 15 & 9 & 6 & 5.77 \\
\hline 5 & 63 & 16 & 7 & 4 & 3 & 3.96 & 129 & 33 & 15 & 9 & 6 & 5.67 & 136 & 34 & 16 & 9 & 6 & 5.82 \\
\hline 6 & 102 & 26 & 12 & 7 & 5 & 5.05 & 126 & 32 & 14 & 8 & 6 & 5.61 & 158 & 40 & 18 & 10 & 7 & 6.28 \\
\hline 7 & 95 & 24 & 11 & 6 & 4 & 4.85 & 193 & 49 & 22 & 13 & 8 & 6.94 & 261 & 66 & 29 & 17 & 11 & 8.07 \\
\hline 8 & 88 & 22 & 10 & 6 & 4 & 4.69 & 139 & 35 & 16 & 9 & 6 & 5.89 & 218 & 55 & 25 & 14 & 9 & 7.38 \\
\hline 9 & 228 & 57 & 26 & 15 & 10 & 7.55 & 349 & 88 & 39 & 22 & 14 & 9.34 & 308 & 77 & 35 & 20 & 13 & 8.76 \\
\hline 10 & 349 & 88 & 39 & 22 & 14 & 9.33 & 519 & 130 & 58 & 33 & 21 & 11.38 & 627 & 157 & 70 & 40 & 26 & 12.51 \\
\hline 11 & 36 & 9 & 4 & 3 & 2 & 2.98 & 546 & 137 & 61 & 35 & 22 & 11.68 & 534 & 134 & 60 & 34 & 22 & 11.55 \\
\hline \multicolumn{19}{|c|}{ Sowing date $2(05 / 25 / 2016)$} \\
\hline 1 & 166 & 42 & 19 & 11 & 7 & 6.43 & 36 & 9 & 4 & 3 & 2 & 2.99 & $-(1)$ & - & - & - & - & - \\
\hline 2 & 119 & 30 & 14 & 8 & 5 & 5.44 & 105 & 27 & 12 & 7 & 5 & 5.12 & 117 & 30 & 13 & 8 & 5 & 5.40 \\
\hline 3 & 113 & 29 & 13 & 8 & 5 & 5.30 & 165 & 42 & 19 & 11 & 7 & 6.40 & 92 & 23 & 11 & 6 & 4 & 4.78 \\
\hline 4 & 70 & 18 & 8 & 5 & 3 & 4.16 & 128 & 32 & 15 & 8 & 6 & 5.64 & 144 & 36 & 16 & 9 & 6 & 5.99 \\
\hline 5 & 72 & 18 & 8 & 5 & 3 & 4.21 & 173 & 44 & 20 & 11 & 7 & 6.57 & 182 & 46 & 21 & 12 & 8 & 6.74 \\
\hline 6 & 72 & 18 & 8 & 5 & 3 & 4.24 & 112 & 28 & 13 & 7 & 5 & 5.28 & 148 & 37 & 17 & 10 & 6 & 6.08 \\
\hline 7 & 63 & 16 & 7 & 4 & 3 & 3.94 & 205 & 52 & 23 & 13 & 9 & 7.15 & 422 & 106 & 47 & 27 & 17 & 10.27 \\
\hline 8 & 65 & 17 & 8 & 5 & 3 & 4.01 & 363 & 91 & 41 & 23 & 15 & 9.52 & 587 & 147 & 66 & 37 & 24 & 12.10 \\
\hline 9 & 275 & 69 & 31 & 18 & 11 & 8.28 & 572 & 143 & 64 & 36 & 23 & 11.96 & 626 & 157 & 70 & 40 & 26 & 12.50 \\
\hline 10 & 52 & 13 & 6 & 4 & 3 & 3.6 & 680 & 170 & 76 & 43 & 28 & 13.03 & 920 & 230 & 103 & 58 & 37 & 15.16 \\
\hline \multicolumn{19}{|c|}{ Sowing date $3(06 / 07 / 2016)$} \\
\hline 1 & 159 & 40 & 18 & 10 & 7 & 6.30 & 113 & 29 & 13 & 8 & 5 & 5.29 & - & - & - & - & - & - \\
\hline 2 & 109 & 28 & 13 & 7 & 5 & 5.22 & 68 & 17 & 8 & 5 & 3 & 4.11 & 106 & 27 & 12 & 7 & 5 & 5.13 \\
\hline 3 & 78 & 20 & 9 & 5 & 4 & 4.39 & 90 & 23 & 10 & 6 & 4 & 4.74 & 105 & 27 & 12 & 7 & 5 & 5.11 \\
\hline 4 & 63 & 16 & 7 & 4 & 3 & 3.95 & 108 & 27 & 12 & 7 & 5 & 5.19 & 115 & 29 & 13 & 8 & 5 & 5.35 \\
\hline 5 & 58 & 15 & 7 & 4 & 3 & 3.79 & 164 & 41 & 19 & 11 & 7 & 6.39 & 150 & 38 & 17 & 10 & 6 & 6.11 \\
\hline 6 & 48 & 12 & 6 & 3 & 2 & 3.46 & 120 & 30 & 14 & 8 & 5 & 5.46 & 134 & 34 & 15 & 9 & 6 & 5.77 \\
\hline 7 & 58 & 15 & 7 & 4 & 3 & 3.79 & 254 & 64 & 29 & 16 & 11 & 7.96 & 179 & 45 & 20 & 12 & 8 & 6.67 \\
\hline 8 & 105 & 27 & 12 & 7 & 5 & 5.12 & 284 & 71 & 32 & 18 & 12 & 8.42 & 258 & 65 & 29 & 17 & 11 & 8.03 \\
\hline 9 & 415 & 104 & 47 & 26 & 17 & 10.18 & 374 & 94 & 42 & 24 & 15 & 9.66 & 358 & 90 & 40 & 23 & 15 & 9.45 \\
\hline 10 & 43 & 11 & 5 & 3 & 2 & 3.26 & 486 & 122 & 54 & 31 & 20 & 11.02 & 426 & 107 & 48 & 27 & 18 & 10.31 \\
\hline
\end{tabular}


continuation

\begin{tabular}{|c|c|c|c|c|c|c|c|c|c|c|c|c|c|c|c|c|c|c|}
\hline \multicolumn{19}{|c|}{ Sowing date $4(06 / 22 / 2016)$} \\
\hline 1 & 162 & 41 & 18 & 11 & 7 & 6.35 & 127 & 32 & 15 & 8 & 6 & 5.61 & - & - & - & & - & - \\
\hline 2 & 64 & 16 & 8 & 4 & 3 & 3.99 & 42 & 11 & 5 & 3 & 2 & 3.22 & 62 & 16 & 7 & 4 & 3 & 3.92 \\
\hline 3 & 62 & 16 & 7 & 4 & 3 & 3.91 & 76 & 19 & 9 & 5 & 4 & 4.35 & 83 & 21 & 10 & 6 & 4 & 4.55 \\
\hline 4 & 64 & 16 & 8 & 4 & 3 & 3.97 & 122 & 31 & 14 & 8 & 5 & 5.52 & 88 & 22 & 10 & 6 & 4 & 4.67 \\
\hline 5 & 69 & 18 & 8 & 5 & 3 & 4.14 & 81 & 21 & 9 & 6 & 4 & 4.49 & 96 & 24 & 11 & 6 & 4 & 4.88 \\
\hline 6 & 55 & 14 & 7 & 4 & 3 & 3.69 & 161 & 41 & 18 & 11 & 7 & 6.34 & 129 & 33 & 15 & 9 & 6 & 5.68 \\
\hline 7 & 39 & 10 & 5 & 3 & 2 & 3.12 & 152 & 38 & 17 & 10 & 7 & 6.16 & 143 & 36 & 16 & 9 & 6 & 5.97 \\
\hline 8 & 45 & 12 & 5 & 3 & 2 & 3.34 & 243 & 61 & 27 & 16 & 10 & 7.78 & 180 & 45 & 20 & 12 & 8 & 6.71 \\
\hline 9 & 296 & 74 & 33 & 19 & 12 & 8.60 & 308 & 77 & 35 & 20 & 13 & 8.76 & 356 & 89 & 40 & 23 & 15 & 9.43 \\
\hline 10 & 50 & 13 & 6 & 4 & 2 & 3.51 & 506 & 127 & 57 & 32 & 21 & 11.24 & 598 & 150 & 67 & 38 & 24 & 12.22 \\
\hline \multicolumn{19}{|c|}{ Sowing date $5(07 / 04 / 2016)$} \\
\hline 1 & 121 & 31 & 14 & 8 & 5 & 5.49 & 51 & 13 & 6 & 4 & 3 & 3.56 & 203 & 51 & 23 & 13 & 9 & 7.11 \\
\hline 2 & 109 & 28 & 13 & 7 & 5 & 5.22 & 126 & 32 & 14 & 8 & 6 & 5.60 & 179 & 45 & 20 & 12 & 8 & 6.67 \\
\hline 3 & 79 & 20 & 9 & 5 & 4 & 4.43 & 201 & 51 & 23 & 13 & 9 & 7.08 & 122 & 31 & 14 & 8 & 5 & 5.51 \\
\hline 4 & 65 & 17 & 8 & 5 & 3 & 4.02 & 136 & 34 & 16 & 9 & 6 & 5.81 & 110 & 28 & 13 & 7 & 5 & 5.23 \\
\hline 5 & 60 & 15 & 7 & 4 & 3 & 3.84 & 178 & 45 & 20 & 12 & 8 & 6.67 & 201 & 51 & 23 & 13 & 9 & 7.08 \\
\hline 6 & 49 & 13 & 6 & 4 & 2 & 3.49 & 229 & 58 & 26 & 15 & 10 & 7.56 & 242 & 61 & 27 & 16 & 10 & 7.77 \\
\hline 7 & 55 & 14 & 7 & 4 & 3 & 3.70 & 264 & 66 & 30 & 17 & 11 & 8.12 & 324 & 81 & 36 & 21 & 13 & 8.99 \\
\hline 8 & 127 & 32 & 15 & 8 & 6 & 5.63 & 364 & 91 & 41 & 23 & 15 & 9.53 & 266 & 67 & 30 & 17 & 11 & 8.14 \\
\hline 9 & 533 & 134 & 60 & 34 & 22 & 11.54 & 501 & 126 & 56 & 32 & 21 & 11.19 & 579 & 145 & 65 & 37 & 24 & 12.03 \\
\hline 10 & 46 & 12 & 6 & 3 & 2 & 3.39 & 886 & 222 & 99 & 56 & 36 & 14.88 & 580 & 145 & 65 & 37 & 24 & 12.04 \\
\hline
\end{tabular}

(1)It was not possible to calculate the sample size because there was no variance in the data (plants presented only one stem).

With the option of sampling 100 plants, the estimation error for the BRS Progresso cultivar would be at most $\pm 7.41,11.63$, and $13.61 \%$ of the mean, respectively, for traits $\mathrm{PH}, \mathrm{NL}$, and NS (Table 5). Meanwhile for the Temprano cultivar, sampling the same number of plants, there would be maximum estimation errors of $\pm 11.54,14.88$, and $15.16 \%$ of the mean, respectively, for the traits $\mathrm{PH}$, NL, and NS (Table 6).

There was a requirement of smaller sample sizes for PH trait in evaluations at the end-of-cycle (flowering stage) and greater sample sizes for NL and NS traits (Tables 5,6). The smaller number of plants for sampling plant height also was found in end-ofcycle evaluations in Crotalaria spectabilis (TOEBE et al., 2017). In general, sample sizes were smaller at sowing dates 3 and 4, indicating that the plants from these sowing dates are more homogeneous. In black oat, sample sizes for intermediate evaluation times were greater than in the initial and final evaluation times (CARGNELUTTI FILHO et al., 2015). With the variability found between the traits evaluated in the rye crop, it is evident that the volume of data collected was representative for the crop. Consequently, the sample size to estimate the mean of these traits can be taken as reference for future studies with this crop.

\section{Conclusion}

There is variability of sample size estimate between traits plant height, number of leaves, and number of stems, between cultivars BRS Progresso and Temprano, between sowing dates, and between evaluation times. Larger sample sizes were required for the Temprano cultivar than the BRS Progresso cultivar. For the BRS Progresso cultivar, 25, 61, and 83 plants were required to estimate mean plant height, number of leaves, and number of stems, respectively, with a maximum estimation error of 15\%. For the Temprano cultivar, 60, 99, and 103 plants were required to estimate mean plant height, 
number of leaves, and number of stems, respectively, with a maximum estimation error of $15 \%$.

\section{Acknowledgments}

We thank the Brazilian National Council for Scientific and Technological Development (CNPq) and the Coordination for the Improvement of Higher Education Personnel (CAPES) for granting scholarships. Our acknowledgement to the Embrapa Trigo, for donating the rye, cultivar BRS Progesso seeds that were used in this study, as well as scholarship students for their help in data collection.

\section{References}

BAIER, A. C. Centeio. Passo Fundo: EMBRAPA, 1994. 29 p. (Documento, 15).

BUSSAB, W. O.; MORETTIN, P. A. Estatística básica. São Paulo: Saraiva, 2013. 548 p.

CAMPOS, H. Estatística experimental não-paramétrica. 4. ed. Piracibaba: Escola Superior de Agricultura Luiz de Queiroz da Universidade de São Paulo, 1983. 349 p.

CARGNELUTTI FILHO, A.; EVANGELISTA, D. H. R.; GONÇALVES, E. C. P.; STORCK, L. Tamanho de amostra de caracteres de genótipos de soja. Ciência Rural, Santa Maria, v. 39, n. 4, p. 983-991, 2009.

CARGNELUTTI FILHO, A.; LOPES, S. J.; BRUM, B.; SILVEIRA, T. R.; TOEBE, M.; STORCK, L. Tamanho de amostra de caracteres em híbridos de mamoneira. Ciência Rural, Santa Maria, v. 40, n. 2, p. 280-287, 2010.

CARGNELUTTI FILHO, A.; TOEBE, M.; ALVES, B. M.; BURIN, C.; SANTOS, G. O.; FACCO, G.; NEU, I. M. M. Dimensionamento amostral para avaliar caracteres morfológicos e produtivos de aveia preta em épocas de avaliação. Ciência Rural, Santa Maria, v. 45, n. 1, p. 9-13, 2015.

COMPANHIA NACIONAL DE ABASTECIMENTO CONAB. Acompanhamento da safra brasileira de grãos, v. 4 - Safra 2016/17, n. 8 - Oitavo levantamento. Brasília: Conab, 2017. Disponível em: <http://www.conab.gov. br/OlalaCMS/uploads/arquivos/17_05_12_10_37_57_ boletim_graos_maio_2017.pdf $>$. Disponível em: $15 \mathrm{fev}$. 2018.

CRUZ, C. D. GENES - a software package for analysis in experimental statistics and quantitative genetics. Acta
Scientiarum. Agronomy, Maringá, v. 35, n. 3, p. 271-276, 2013.

FACCO, G.; CARGNELUTTI FILHO, A.; ALVES, B. M.; BURIN, C.; SANTOS, G. O.; KLEINPAUL, J. A.; NEU, I. M. M. Sample size for estimating average productive traits of pigeon pea. Ciência Rural, Santa Maria, v. 46, n. 4, p. 619-625, 2016.

FACCO, G.; CARGNELUTTI FILHO, A.; LÚCIO, A. D.; SANTOS, G. O.; STEFANELlO, R. B.; ALVES, B. M.; BURIN, C.; NEU, I. M. M.; KLEINPAUL, J. A. Sample size for morphological traits of pigeonpea. Semina: Ciências Agrárias, Londrina, v. 36, n. 6, p. 4151-4164, 2015.

HELDWEIN, A. B.; BURIOL, G. A.; STRECK, N. A. O clima de Santa Maria. Ciência \& Ambiente, Santa Maria,v. 38, n. 1, p. 43-58, 2009.

LIN, M.; LUCAS, H. C.; SHMUELI, G. Too big to fail: large samples and the $\mathrm{p}$-value problem. Information Systems Research, Catonsville, v. 24, n. 4, p. 906-917, 2013.

PANTOJA, J.L.; WOLI, K. P.; SAWYER, J.E.; BARKER, D. W. Winter rye cover crop biomass production, degradation, and nitrogen recycling. Agronomy Journal, Madison, v. 108, n. 2, p. 841-853, 2016.

SANTOS, H. G.; JACOMINE, P. K. T.; ANJOS, L. H. C.; OLIVEIRA, V. A.; LUMBRERAS, J. F.; COELHO, M. R.; ALMEIDA, J. A.; CUNHA, T. J. F.; OLIVEIRA, J. B. Sistema brasileiro de classificação de solos. 3. ed. Brasília: Embrapa, 2013. 353 p.

STORCK, L.; LOPES, S. J.; CARGNELUTTI FILHO, A.; MARTINI, L. F. D.; CARVALHO, M. P. Sample size for single, double and three-way hybrid corn ear traits. Scientia Agricola, Piracicaba, v. 64, n. 1, p. 30-35, 2007.

TEODORO, P. E.; SILVA JUNIOR, C. A.; RIBEIRO, L. P.; SILVA, F. A.; CORRÊA, C. C. G.; ZANUNCIO, A. S.; TORRES, F. E. Sample dimension for estimation of biomass and yield of sunn (Crotalaria juncea L.) and showy rattlebox (C. spectabilis Roth.). Journal of Agronomy, Faisalabad, v. 14, n. 2, p. 98-101, 2015.

TOEBE, M.; BANDEIRA, C. T.; FORTES, S. K. G.; CARVALHO, J. O.; TARTAGLIA, F. L.; TAMBARA, A. L.; MELO, P. J. Dimensionamento amostral e associação linear entre caracteres de Crotalaria spectabilis. Bragantia, Campinas, v. 76, n. 1, p. 45-53, 2017.

ZIECH, A. R. D.; CONCEIÇÃO, P. C.; LUCHESE, A. V.; BALIN, N. M.; CANDIOTTO, G.; GARMUS, T. G. Proteção do solo por plantas de cobertura de ciclo hibernal na região Sul do Brasil. Pesquisa Agropecuária Brasileira, Brasília, v. 50, n. 5, p. 374-382, 2015. 